\title{
Pendugaan sebaran intrusi air laut melalui sungai di desa Ujungmanik kecamatan Kawunganten kabupaten Cilacap menggunakan metode geolistrik resistivitas konfigurasi Wenner
}

\author{
Mitha Syahfitri*, Sehah, Sunardi \\ Program Studi Fisika, Fakultas MIPA, Universitas Jenderal Soedirman \\ Jalan Dr. Suparno No.61 Karangwangkal Purwokerto Jawa Tengah \\ email: mithasyahfitri28@gmail.com
}

\begin{abstract}
Abstrak - Pendugaan sebaran intrusi air laut melalui sungai di Desa Ujungmanik Kecamatan Kawunganten Kabupaten Cilacap telah dilakukan menggunakan metode geolistrik resistivitas dengan konfigurasi Wenner. Penelitian bertujuan untuk melakukan pendugaan sebaran intrusi air laut melalui sungai di Desa Ujungmanik, Kecamatan Kawunganten, Kabupaten Cilacap berdasarkan data geolistrik resistivitas dan konduktivitas air tanah. Akuisisi data geolistrik dilakukan pada empat lintasan yaitu lintasan Wen1, lintasan Wen2, lintasan Wen3, dan lintasan Wen4. Setiap lintasan memiliki panjang bentangan sebesar $200 \mathrm{~m}$. Hasil pengolahan data resistivitas menunjukkan struktur batuan bawah permukaan yang terdiri atas pasir, lempung, lempung pasiran, dan pasir lempungan. Intrusi air laut diindikasikan telah terjadi di seluruh lintasan pada lapisan pasir, karena memiliki range nilai resistivitas yang sangat rendah, yaitu berkisar $0,20-2,79 \Omega \mathrm{m}$. Pengambilan sampel air tanah dilakukan pada 15 titik dengan nilai konduktivitas bervariasi antara $1.363-4.145 \mu \mathrm{S} / \mathrm{cm}$ sehingga dapat digolongkan ke dalam kelompok air tawar dan air agak payau, dikarenakan sampel-sampel air diambil pada musim hujan. Berdasarkan hasil penelitian, Desa Ujungmanik diperkirakan terintrusi air laut secara merata, khususnya pada koordinat $7^{\circ} 38^{\prime} 15.62^{\prime \prime}$ LS dan 108 57'20.89" BT hingga $7^{\circ} 39^{\prime} 22.86^{\prime \prime}$ LS dan 108 $56^{\prime} 35.33^{\prime \prime}$ BT.
\end{abstract}

Kata kunci: intrusi air laut, metode geolistrik, Desa Ujungmanik, konduktivitas

Abstract - - The interpretation of the distribution of the sea water intrusion through the rivers in the Ujungmanik Village, Kawunganten District, Cilacap Regency has been done using the geoelectric resistivity method with Wenner configuration. This research aims to estimate the distribution of sea water intrusion through rivers in Ujungmanik Village, Kawunganten District, Cilacap Regency based on the subsurface rock resistivity data and groundwater conductivity data. The geoelectrical data acquisition was carried out on four lines. They were Wen1, Wen2, Wen3, and Wen4 trajectories. Each trajectory have a length of $200 \mathrm{~m}$. The results of resistivity data processing showed that the subsurface rock structure consisted of sand, clay, sandy clay, and clayey sand. Seawater intrusion is indicated to have occurred throughout the trajectories in the sand layer, because it has a very low resistivity value range, which is around $0.20-2.79 \Omega \mathrm{m}$. Groundwater samples was carried out at 15 points with the conductivity value varies between $1.363-4.145 \mu \mathrm{S} / \mathrm{cm}$ so they can be classified into the freshwater and slightly brackish water groups, because the samples were taken during the rainy season. Based on the research results, it is estimated that Ujungmanik Village is evenly distributed by sea water, especially at coordinates of $7^{\circ} 38^{\prime} 15.62^{\prime \prime} S$ and $108^{\circ} 57^{\prime} 20.89^{\prime \prime} E$ to $7^{\circ} 39^{\prime 2} 22.86^{\prime \prime} L S$ and $108^{\circ} 56^{\prime} 35.33^{\prime \prime B T}$.

Key words: seawater intrusion, geoelectric method, Ujungmanik Village, conductivity

\section{PENDAHULUAN}

Air merupakan salah satu sumberdaya alam yang sangat dibutuhkan oleh semua makhluk hidup di permukaan bumi. Salah satu jenis air tawar yang digunakan manusia untuk memenuhi kebutuhan sehari-hari adalah air tanah [1]. Air tanah banyak digunakan untuk memenuhi kebutuhan hidup manusia dan makhluk hidup lainnya karena beberapa alasan, salah satunya adalah memiliki kualitas yang lebih baik serta lebih sulit mengalami pencemaran daripada air permukaan [2]. Namun demikian ada beberapa kelemahan jika terjadi pengambilan air tanah yang berlebihan, yaitu (1) penurunan ketersediaan air tanah dan berkurangnya debit air di dalam lapisan akuifer sehingga mengurangi produksi air tanah, (2) penurunan muka air tanah secara besar-besaran sehingga air sulit dan mahal didapatkan, (3) intrusi air laut, (4) terjadinya longsor dan retakan di permukaan tanah [3].

Intrusi air laut merupakan suatu peristiwa penyusupan atau peresapan air laut ke lapisan 
akuifer air tanah. Kasus intrusi air laut merupakan masalah yang sering terjadi di daerah pesisir pantai. Selain terjadi di daerah pesisir, intrusi air laut juga bisa terjadi di daerah muara sungai yang dekat dengan laut [2]. Intrusi air laut melalui sungai diduga terjadi di Desa Ujungmanik, Kecamatan Kawunganten, Kabupaten Cilacap [4]. Beberapa sumur penduduk di Desa Ujungmanik khususnya sekitar sungai, airnya terasa asin [5]. Di sekitar Sungai Ujungmanik ini juga ditumbuhi tanaman mangrove yang biasanya hidup di habitatnya. yaitu kawasan pesisir. Kondisi ini mengindisikan air sumur dan daerah di sekitar sungai tersebut telah terintrusi air laut. Oleh sebab itu, perlu dilakukan penelitian untuk mengetahui titik-titik akuifer lain yang terintrusi air laut.

Persebaran daerah yang terkena intrusi air laut melalui sungai dapat diidentifikasi menggunakan salah satu survei geofisika yaitu metode geolistrik resistivitas. Survei metode resistivitas merupakan salah satu metode geofisika yang mempelajari sifat resistivitas batuan di dalam bumi. Prinsip metode resistivitas adalah dengan mengalirkan arus listrik ke dalam bumi melalui kontak dua elektroda arus, kemudian diukur distribusi potensial yang dihasilkan [6]. Konfigurasi yang digunakan di dalam penelitian ini adalah konfigurasi Wenner. Konfigurasi Wenner merupakan metode resistivitas mapping sehingga cocok digunakan untuk mengidentifikasi sebaran intrusi air laut dan model penampang batuan bawah permukaan [7]. Untuk memperkuat hasil-hasil penelitian, uji konduktivitas terhadap beberapa sampel air tanah dilakukan. Selanjutnya untuk menggambarkan seberapa jauh intrusi air laut terjadi di daerah penelitian, maka dilakukan korelasi penampang litologi batuan bawah permukaan antar lintasan.

\section{LANDASAN TEORI}

\section{A. Metode Geolistrik Resistivitas}

Metode geolistrik merupakan salah satu metode geofisika yang dapat digunakan untuk menggambarkan keberadaan batuan atau mineral di bawah permukaan berdasarkan sifat kelistrikan batuan atau mineral. Salah satu metode geolistrik yang sering digunakan untuk mengetahui sifat tahanan jenis atau resistivitas batuan bawah permukaan adalah metode geolistrik resistivitas. Metode resistivitas dilakukan dengan cara menginjeksikan arus listrik melalui dua buah elektroda arus ke permukaan bumi yang kemudian diukur nilai beda potensialnya melalui dua buah elektroda potensial. Secara umum pendekatan yang digunakan untuk mendapatkan nilai resistivitas setiap medium di bawah permukaan bumi yaitu dengan mengasumsikan bahwa bumi adalah suatu medium yang homogen isotropis. Bumi diasumsikan sebagai suatu medium yang homogen isotropis artinya bumi memiliki distribusi batuan yang merata dan seragam sehingga arus yang dialirkan melalui sebuah elektroda di permukaan akan tersebar ke seluruh arah dengan besar yang sama [8]. Nilai resistivitas yang dihasilkan merupakan nilai resistivitas semu yang dapat dihitung dengan persamaan [9]:

$$
\rho_{a}=K \frac{\Delta V}{I}
$$

di mana $\rho_{a}$ adalah resistivitas semu, $K$ adalah faktor geometri, $\Delta V$ adalah beda potensial, dan $I$ adalah kuat arus. Besar faktor geometri tergantung dari jenis konfigurasi yang digunakan. Konfigurasi Wenner mempunyai susunan jarak spasi antar elektroda sama panjang seperti pada Gambar 1. Besarnya faktor geometri untuk konfigurasi Wenner dapat dinyatakan dengan persamaan:

$$
K=2 \pi a
$$

dimana $a$ adalah spasi antar elektroda yang digunakan. Dari persamaan (1), nilai resistivitas semu konfigurasi Wenner dapat dituliskan :

$$
\rho_{a}=2 \pi a \frac{\Delta V}{I}
$$

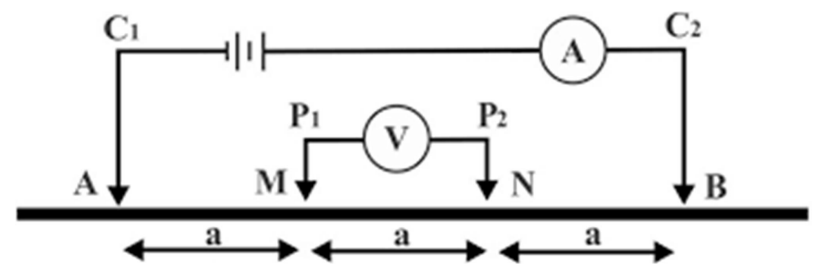

Gambar 1. Susunan elektroda konfigurasi Wenner yang digunakan pada saat akuisisi data geolistrik resistivitas [10].

Nilai resistivitas sebenarnya (true resistivty) dihasilkan melalui pemodelan terhadap resistivitas semu menggunakan perangkat lunak (software) tertentu. Nilai resistivitas yang diperoleh selanjutnya diinterpretasi untuk 
menafsirkan jenis litologi masing-masing lapisan batuan bawah permukaan. Interpretasi ini didasarkan atas informasi geologi setempat dan tabel nilai resistivitas batuan seperti ditunjukkan pada Tabel 1 [9]. Tabel tersebut menunjukkan hasil pengukuran nilai resistivitas batuan dan material lain di laboratorium dan bukan di lapangan. Umumnya pengukuran nilai resistivitas di lapangan dipengaruhi oleh banyak faktor, salah satunya adalah heterogenitas lapisan batuan. Oleh sebab itu di dalam proses interpretasi litologi, informasi dan analisis geologi sangat diperlukan.

Tabel 1. Tabel resistivitas batuan dan material lain [9]

\begin{tabular}{ll}
\hline Material & Resistivitas $(\Omega \mathrm{m})$ \\
\hline Udara & $\sim$ \\
Kuarsa & $500-800.000$ \\
Garam batu & $30-1 \times 10^{13}$ \\
Granit & $200-10.000$ \\
Andesit & $1.700-45.000$ \\
Basaltik & $200-100.000$ \\
Gamping & $500-10.000$ \\
Batupasir & $200-8.000$ \\
Pasir & $1-1.000$ \\
Lempung & $1-100$ \\
Air tanah & $0,5-300$ \\
Air asin & 0,2 \\
Kerikil kering & $600-10.000$ \\
Alluvium & $10-800$ \\
Kerikil & $100-600$ \\
\hline
\end{tabular}

\section{B. Intrusi Air Laut}

Intrusi air laut adalah menyusupnya air laut ke dalam pori-pori batuan dan mencemari air tanah yang terkandung di dalamnya sehingga mengakibatkan air tanah berubah menjadi air payau atau bahkan asin [11]. Hubungan antara air asin dengan air tawar seperti ditunjukkan pada Gambar 2 yang memenuhi persamaan hidrostatis fluida:

$$
\rho_{s} g z=\rho_{f} g(z+h)
$$

di mana $\rho_{f}$ adalah densitas air tawar $\left(\mathrm{kg} / \mathrm{m}^{3}\right), \rho_{s}$ adalah densitas air asin $\left(\mathrm{kg} / \mathrm{m}^{3}\right), g$ adalah percepatan gravitasi $\left(\mathrm{m} / \mathrm{s}^{2}\right), z$ adalah kedalaman interface air tanah-air asin dari mean sea level (m) dan $h$ adalah ketinggian muka air tanah dari mean sea level $(\mathrm{m})$.

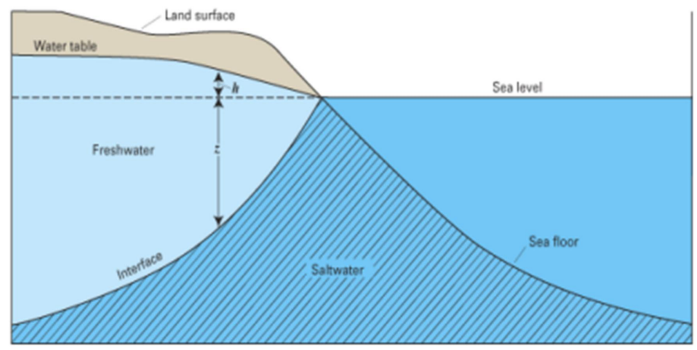

Gambar 2. Hubungan antara air tawar dengan air asin [12]

Pada kondisi normal air laut tidak dapat masuk jauh ke daratan sebab airtanah memiliki piezometric yang menekan lebih kuat daripada air laut, sehingga terbentuklah interface sebagai batas antara air tanah dengan air laut. Keadaan tersebut merupakan keadaan kesetimbangan antara air laut dan air tanah. Namun pada saat keadaan kesetimbangan ini terganggu, maka air laut terus mendesak air tanah semakin ke hulu sehingga terjadi intrusi air laut [13]. Keadaan interface secara normal dan interface mengalami intrusi dapat dilihat pada Gambar 3.

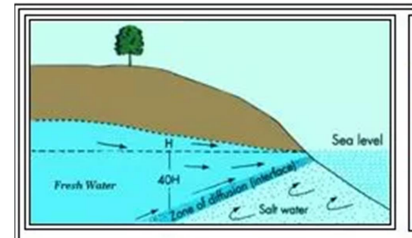

(a)

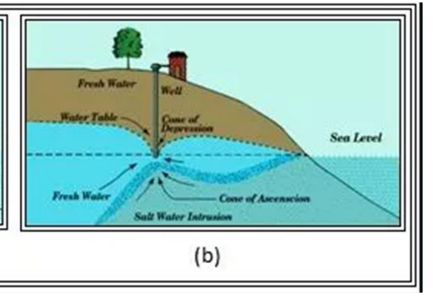

(b)
Gambar 3. (a) Keadaan interface alami, (b) Interface mengalami intrusi [14]

\section{Konduktivitas Air Tanah}

Konduktivitas adalah gambaran numerik kemampuan air untuk meneruskan aliran listrik. Pengukuran konduktivitas air tanah dilakukan dengan alat Electric Conductivity (EC) meter, satuan yang umum digunakan adalah mikro Siemen per centimeter $(\mu \mathrm{S} / \mathrm{cm})$ yang setara dengan $\mu \mathrm{mhos} / \mathrm{cm}$ [15]. Klasifikasi air tanah berdasarkan nilai konduktivitas listrik tercantum pada Tabel 2. 
Tabel 2. Klasifikasi air tanah berdasarkan konduktivitas listrik [16]

\begin{tabular}{lll}
\hline Sifat Air & $\begin{array}{l}\text { Daya Hantar } \\
(\mu \mathrm{S} / \mathrm{cm})\end{array}$ & Listrik \\
\hline Air Tawar & $<1.500$ \\
Air Agak Payau & $1.500-5000$ & \\
Air Payau & $5.000-15.000$ & \\
Air Asin & $15.000-50.000$ & \\
\hline
\end{tabular}

\section{Geologi Daerah Penelitian}

Berdasarkan Peta Geologi Lembar Pangandaran [17], formasi batuan Desa Ujungmanik Kecamatan Kawunganten Kabupaten Cilacap terdiri dari:

\section{a. Endapan Aluvial (Qa)}

Formasi ini merupakan endapan permukaan yang terdiri atas lumpur, pasir, kerikil, dan kerakal

b. Formasi Halang (Tmph)

Formasi ini merupakan endapan turbidit yang terdiri atas perselingan antara batunapal, kalkarenit, batupasir sela, konglomerat dengan sisipan batugamping, dan batupasir kerikil di bagian bawah, batunapal semakin dominan di bagian atas.

Dua formasi batuan ini dijadikan acuan pada saat dilakukan proses pemodelan dan interpretasi.

\section{METODE PENELITIAN}

Penelitian ini telah dilakukan pada bulan Januari 2020 hingga Juli 2020. Akuisisi data geolistrik dilakukan di Desa Ujungmanik Kecamatan Kawunganten Kabupaten Cilacap menggunakan metode geolistrik konfigurasi Wenner. Lintasan yang diambil sebanyak 4 lintasan dengan panjang bentangan setiap lintasan yaitu $200 \mathrm{~m}$ seperti pada Gambar 4. Peralatan yang digunakan pada survei resistivitas adalah Resistivitymeter merk NANIURA model NRD$22 \mathrm{~S}$ lengkap dengan alat-alat pendukungnya, Global Positioning System (GPS), peta geologi, lembar kerja data penelitian, alat tulis, aplikasi google earth, laptop, software Res2Dinv 3.54.44, software Voxler 4.0, software Surfer 10 , dan sebagainya.

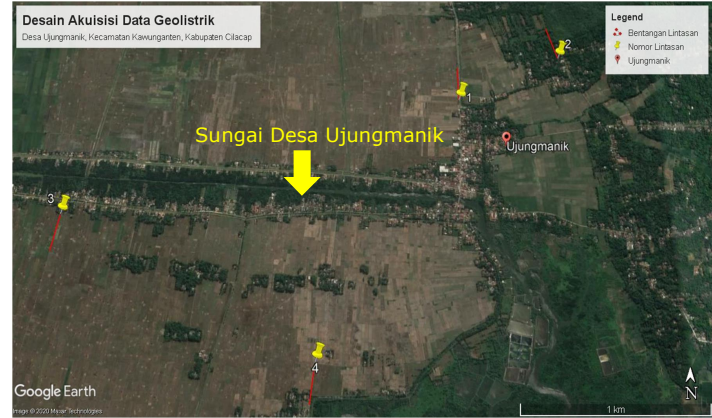

Gambar 4. Desain akuisisi data geolistrik konfigurasi Wenner di Desa Ujungmanik Kecamatan Kawunganten Kabupaten Cilacap

$\begin{array}{ccr}\text { Akuisisi data geolistrik resistivitas } & \text { dengan } \\ \text { konfigurasi } & \text { Wenner dimulai } & \text { dengen }\end{array}$ pemasangan elektroda arus dan elektroda potensial yang disusun seperti Gambar 5. Spasi bentangan antar elektroda sebesar $a$, akan menghasilkan data level pengukuran $n=1$. Nilai kuat arus dan beda potensial yang terukur diperoleh dengan cara menginjeksikan arus ke dalam permukaan bumi melalui elektroda arus. Akibat injeksi arus, maka timbul beda potensial batuan yang diterima elektroda potensial. Akuisisi selanjutnya dilakukan dengan menggeser elektroda ke arah kanan sebesar $a$ hingga jarak maksimum bentangan. Untuk menghasilkan data level pengukuran $n=$ 2,3,4, dst dilakukan dengan cara mengubah spasi antar elektroda sebesar $2 a, 3 a, 4 a$ dst.

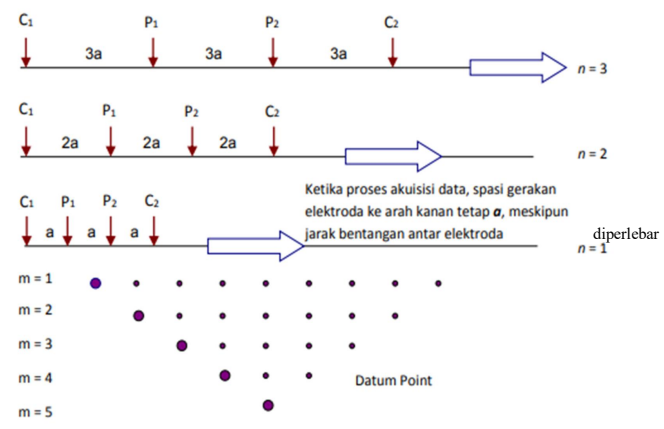

Gambar 5. Pergerakan elektroda arus dan elektroda potensial metode geolistrik resistivitas konfigurasi Wenner [9]

Data yang diperoleh di setiap lintasan pada saat akuisisi data berupa kuat arus listrik (I), beda potensial $(\Delta V)$, dan jarak antar elektroda $(a)$. Adapun faktor geometri $(K)$ dan nilai resistivitas semu $\left(\rho_{a}\right)$ untuk setiap pengukuran data dihitung berdasarkan persamaan (2) dan 
(3). Pemodelan struktur batuan bawah permukaan secara 2D ini dilakukan menggunakan software Res2Dinv 3.54.44. Pemodelan yang digunakan pada software tersebut yaitu metode last-squares inversion dengan mencocokkan kurva model dengan kurva observasi [18]. Persamaan matematis yang digunakan pada metode last-square inversion yaitu:

$$
\left(J^{T} T+\mu F\right) \boldsymbol{d}=J^{T} \boldsymbol{g}-\mu F \boldsymbol{r}
$$

di mana $F=f_{x} f_{x}^{T}+f_{z} f_{z}^{T}$ dengan $f_{x}$ adalah filter flatness horizontal, $f_{z}$ adalah filter flatness vertical, $J$ adalah matriks dari turunan parsial, $\mu$ adalah faktor damping, $\boldsymbol{d}$ adalah vektor perturbasi dari model, $\boldsymbol{g}$ adalah vektor discrepancy, dan $\boldsymbol{r}$ adalah vektor yang logaritma dari nilai [19].

Langkah selanjutnya yaitu melakukan interpretasi untuk menentukan jenis-jenis struktur batuan penyusun bawah permukaan menggunakan software Res2Dinv 3.54.44. Pendugaan struktur batuan penyusun bawah permukaan dapat dilakukan dengan cara pendekatan nilai resistivitas batuan pada tabel standar nilai resistivitas dan informasi kondisi geologi daerah penelitian. Hasil interpretasi tiap lintasan selanjutnya dikorelasikan agar diketahui pola aliran intrusinya. Korelasi antar lintasan dilakukan menggunakan software Voxler 4.0 untuk menghasilkan model penampang resistivitas dan litologi batuan secara 3D.

Pengambilan sampel air tanah dilakukan di 15 titik sekitar lokasi daerah penelitian seperti pada Gambar 6. Peralatan yang digunakan pada pengambilan sampel air tanah yaitu botol, GPS, kamera. Sedangkan peralatan yang digunakan untuk uji konduktivitas sampel air tanah sampai dengan pengolahan data yaitu conductivitymeter tipe TDSEC-2-DB, alat tulis, laptop, Microsoft Excel 2010, Software Surfer 10.

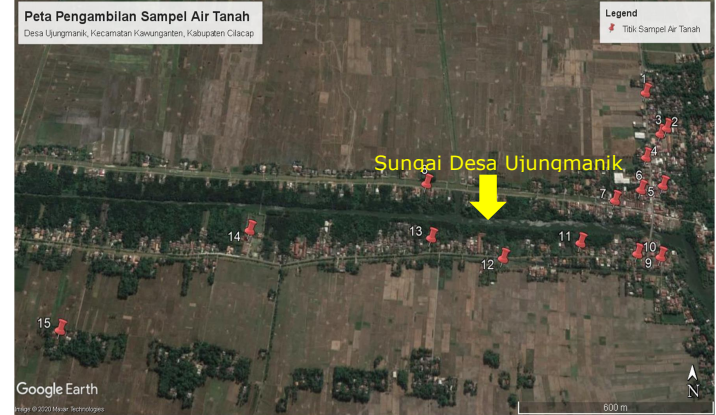

Gambar 6. Titik-titik lokasi pengambilan sampel air tanah di Desa Ujungmanik Kecamatan Kawunganten Kabupaten Cilacap

Sampel air tanah yang telah diambil kemudian dilakukan uji konduktivitasnya menggunakan alat EC-meter. Setelah didapatkan data konduktivitas, kemudian dilakukan analisis perubahan nilai konduktivitas sampel air tanah dengan jarak pengambilan sampel yang diukur dari tepi sungai dalam bentuk grafik.

\section{HASIL DAN PEMBAHASAN}

Akuisisi data geolistrik resistivitas konfigurasi Wenner dan pengambilan sampel air tanah telah dilakukan di Desa Ujungmanik Kecamatan Kawunganten Kabupaten Cilacap. Akuisisi data geolistrik dilakukan pada empat lintasan yang berbeda yaitu lintasan Wen1 hingga lintasan Wen4. Lintasan Wen1 dan lintasan Wen2 berada di bagian utara sungai, adapun lintasan Wen3 dan lintasan Wen4 berada di bagian selatan. Posisi lintasan tegak lurus terhadap sungai dengan lintasan Wen1 dan lintasan Wen2 mengarah dari selatan ke utara, adapun lintasan Wen3 dan lintasan Wen4 mengarah dari utara ke selatan seperti pada Gambar 4.

Pemodelan resistivitas telah dilakukan dan menghasilkan penampang resistivitas batuan bawah permukaan seperti ditunjukkan pada Gambar 7, Gambar 8, Gambar 9, dan Gambar 10. Kedalaman maksimum hasil pemodelan adalah 28,7 meter pada semua lintasan. Penampang resistivitas 2D selanjutnya diinterpretasi untuk mendapatkan penampang litologi batuan bawah permukaan 2D. Hasil interpretasi penampang resistivitas 2D ditunjukkan pada Gambar 11, Gambar 12, Gambar 13, dan Gambar 14. Secara lebih lengkap, hasil interpretasi penampang resistivitas 2D dapat dilihat pada Tabel 3, Tabel 4, Tabel 5, dan Tabel 6. Proses interpretasi mengacu pada informasi geologi 
setempat [17] dan tabel resistivitas batuan sebagaimana telah dijelaskan di bagian

\section{Tinjauan Pustaka.}

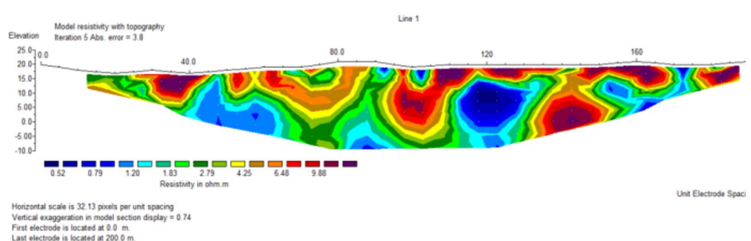

Gambar 7. Penampang resistivitas 2D Lintasan Wen 1

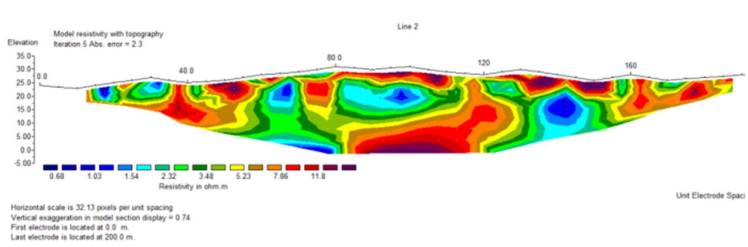

Gambar 8. Penampang resistivitas 2D Lintasan Wen2

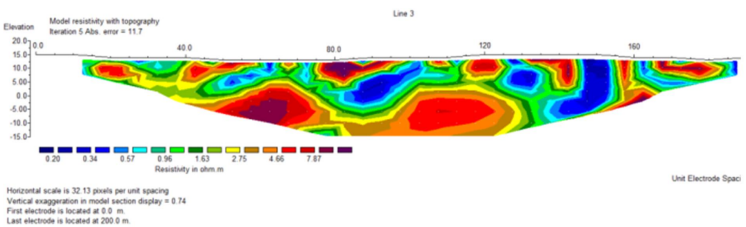

Gambar 9. Penampang resistivitas 2D Lintasan Wen3

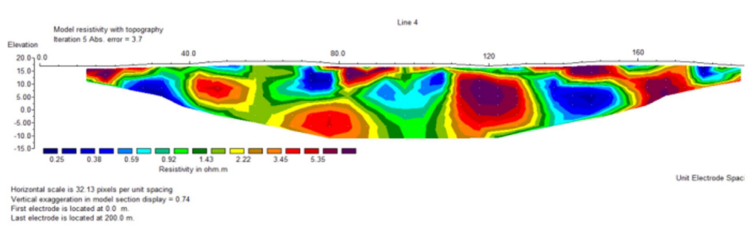

Gambar 10. Penampang resistivitas 2D Lintasan Wen4

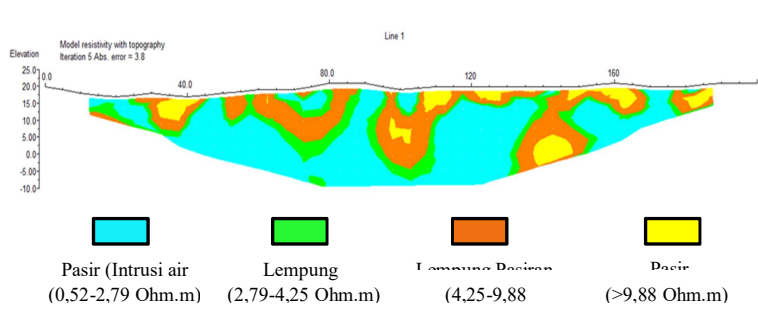

Gambar 11. Interpretasi penampang resistivitas 2D dengan kontur skala litologi batuan pada Lintasan Wen 1

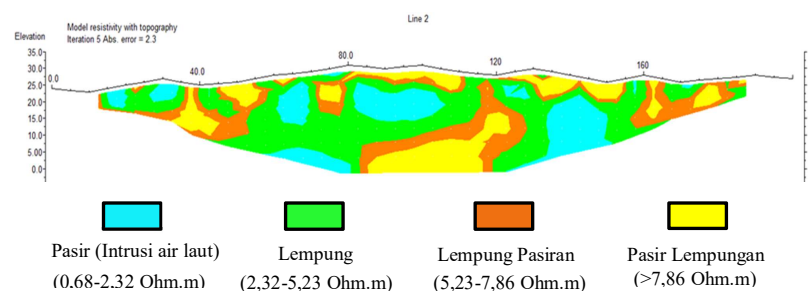

Gambar 12. Interpretasi penampang resistivitas 2D dengan kontur skala litologi batuan pada Lintasan Wen2

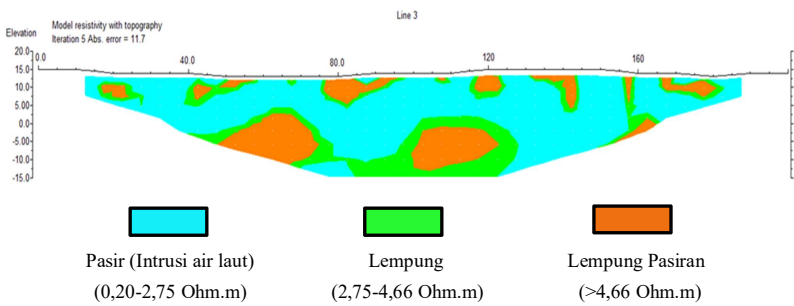

Gambar 13. Interpretasi penampang resistivitas 2D dengan kontur skala litologi batuan pada Lintasan Wen3

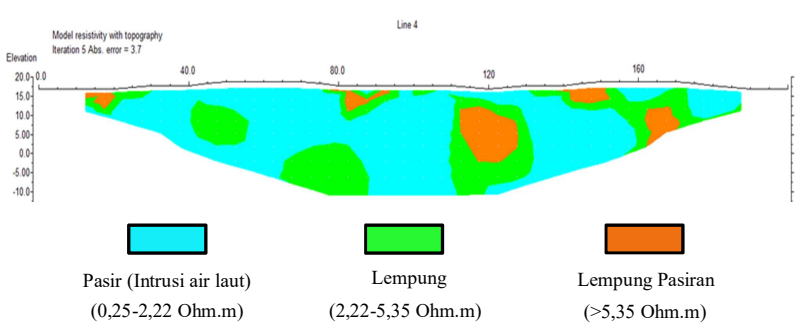

Gambar 14. Interpretasi penampang resistivitas 2D dengan kontur skala litologi batuan pada Lintasan Wen4

Tabel 3. Hasil interpretasi litologi terhadap penampang resistivitas pada lintasan Wen1

\begin{tabular}{|c|c|c|c|c|}
\hline Lapisan & $\begin{array}{l}\text { Resistivitas } \\
(\Omega \mathrm{m})\end{array}$ & $\begin{array}{l}\text { Kedalama } \\
\mathrm{n}( \pm \mathrm{m})\end{array}$ & Litologi & $\begin{array}{l}\text { Air } \\
\text { tanah }\end{array}$ \\
\hline 1 & $>9,88$ & $1,25-23$ & $\begin{array}{l}\text { Pasir } \\
\text { Lempunga } \\
n\end{array}$ & $\begin{array}{l}\text { Air } \\
\text { Payau }\end{array}$ \\
\hline 2 & $4,25-9,88$ & $1,25-25$ & $\begin{array}{l}\text { Lempung } \\
\text { Pasiran }\end{array}$ & $\begin{array}{l}\text { Air } \\
\text { Payau }\end{array}$ \\
\hline 3 & $2,79-4,25$ & $\begin{array}{l}1,25 \\
28,7\end{array}$ & Lempung & $\begin{array}{l}\text { Air } \\
\text { Asin }\end{array}$ \\
\hline 4 & $0,52-2,79$ & $\begin{array}{l}1,25 \\
28,7\end{array}$ & $\begin{array}{l}\text { Pasir } \\
\text { (Intrusi } \\
\text { Air Laut) }\end{array}$ & $\begin{array}{l}\text { Air } \\
\text { Asin }\end{array}$ \\
\hline
\end{tabular}

Catatan: Posisi koordinat $7^{\circ} 38^{\prime} 30.17^{\prime \prime} \mathrm{LS} 108^{\circ} 57^{\prime} 02.98^{\prime \prime} \mathrm{BT}$ hingga $7^{\circ} 38^{\prime} 23.68^{\prime \prime} \mathrm{LS} 108^{\circ} 57^{\prime} 03.02^{\prime \prime} \mathrm{BT}$ 
Tabel 4. Hasil interpretasi litologi terhadap penampang resistivitas pada lintasan Wen2

\begin{tabular}{lllll}
\hline Lapisan & $\begin{array}{l}\text { Resistivitas } \\
(\Omega \mathrm{m})\end{array}$ & $\begin{array}{l}\text { Kedalaman } \\
( \pm \mathrm{m})\end{array}$ & $\begin{array}{l}\text { Litologi } \\
1,25-28,7\end{array}$ & $\begin{array}{l}\text { Pasir } \\
\text { Lempungan } \\
\text { tanah }\end{array}$ \\
\hline 1 & $>7,86$ & $\begin{array}{l}\text { Air } \\
\text { Payau } \\
\text { Air }\end{array}$ \\
2 & $5,23-7,86$ & $1,25-28,7$ & $\begin{array}{l}\text { Lempung } \\
\text { Pasiran }\end{array}$ & $\begin{array}{l}\text { Payau } \\
\text { Air } \\
\text { Asin }\end{array}$ \\
3 & $2,32-5,23$ & $1,25-28,7$ & $\begin{array}{l}\text { Lempung } \\
\text { Pasir } \\
\text { (Intrusi Air } \\
\text { Laut) }\end{array}$ & $\begin{array}{l}\text { Air } \\
\text { Asin }\end{array}$ \\
4 & $0,68-2,32$ & $1,25-28,7$ & \\
\hline
\end{tabular}

Catatan: Posisi koordinat $7^{\circ} 38^{\prime} 21.86^{\prime \prime} \mathrm{LS} 108^{\circ} 57^{\prime} 22.78^{\prime \prime} \mathrm{BT}$ hingga $7^{\circ} 38^{\prime} 15.62^{\prime \prime} \mathrm{LS} 108^{\circ} 57^{\prime} 20.89$ "BT $^{\prime \prime}$

Tabel 5. Hasil interpretasi litologi terhadap penampang resistivitas pada lintasan Wen3

\begin{tabular}{lllll}
\hline Lapisan & $\begin{array}{l}\text { Resistivitas } \\
(\Omega \mathrm{m})\end{array}$ & $\begin{array}{l}\text { Kedalaman } \\
( \pm \mathrm{m})\end{array}$ & Litologi & $\begin{array}{l}\text { Air } \\
\text { tanah }\end{array}$ \\
\hline 1 & $>4,66$ & $1,25-26$ & $\begin{array}{l}\text { Lempung } \\
\text { Pasiran }\end{array}$ & $\begin{array}{l}\text { Air } \\
\text { Payau }\end{array}$ \\
2 & $2,75-4,66$ & $1,25-28,7$ & $\begin{array}{l}\text { Lempung } \\
\text { Air } \\
\text { Asin }\end{array}$ \\
3 & $0,20-2,75$ & $1,25-28,7$ & $\begin{array}{l}\text { Pasir } \\
\text { (Intrusi } \\
\text { Air Laut) }\end{array}$ & $\begin{array}{l}\text { Air } \\
\text { Asin }\end{array}$ \\
\hline
\end{tabular}

Catatan: Posisi koordinat $7^{\circ} 38^{\prime} 51.46^{\prime \prime} L S 108^{\circ} 55^{\prime} 48.63^{\prime \prime B T}$ hingga $7^{\circ} 38^{\prime} 57.85^{\prime \prime} \mathrm{LS} 108^{\circ} 55^{\prime} 47.51^{\prime \prime} \mathrm{BT}$

Tabel 6. Hasil interpretasi litologi terhadap penampang resistivitas pada lintasan Wen4

\begin{tabular}{lllll}
\hline Lapisan & $\begin{array}{l}\text { Resistivitas } \\
(\Omega \mathrm{m})\end{array}$ & $\begin{array}{l}\text { Kedalaman } \\
( \pm \mathrm{m})\end{array}$ & Litologi & $\begin{array}{l}\text { Air } \\
\text { tanah }\end{array}$ \\
\hline 1 & $>5,35$ & $1,25-19,8$ & $\begin{array}{l}\text { Lempung } \\
\text { Pasiran }\end{array}$ & $\begin{array}{l}\text { Air } \\
\text { Payau } \\
\text { Air } \\
\text { Asin }\end{array}$ \\
2 & $2,22-5,35$ & $1,25-28,7$ & $\begin{array}{l}\text { Lempung } \\
\text { Pasir } \\
\text { (Intrusi } \\
\text { Air Laut) }\end{array}$ & $\begin{array}{l}\text { Air } \\
\text { Asin }\end{array}$ \\
3 & $0,25-2,22$ & $1,25-28,7$ &
\end{tabular}

Catatan: Posisi koordinat 7039'16.39"LS 108 ${ }^{\circ} 56^{\prime} 36.12^{\prime \prime} \mathrm{BT}$ hingga $7^{\circ} 39^{\prime} 22.86^{\prime \prime} \mathrm{LS} 108^{\circ} 56^{\prime} 35.33^{\prime \prime} \mathrm{BT}$

Hasil interpretasi terhadap penampang resistivitas batuan bawah permukaan secara 2D menunjukkan bahwa lintasan Wen1 dan Wen2 tersusun dari empat lapisan batuan. Empat lapisan batuan tersebut yaitu pasir lempungan, lempung pasiran, lempung, dan pasir. Sedangkan hasil interpretasi terhadap penampang resistivitas 2D menunjukkan bahwa lintasan Wen3 dan lintasan Wen4 tersusun dari tiga lapisan batuan yang meliputi lempung pasiran, lempung, pasir.

Lapisan pasir yang diduga terintrusi air laut memiliki nilai resistivitas terkecil dengan rentang nilai $0,20-2,79 \Omega \mathrm{m}$. Hal ini didukung dengan adanya penelitian sebelumnya yang dilakukan oleh Purnama dkk [2] menunjukkan bahwa pada range nilai resistivitas $\leq 3,00 \Omega \mathrm{m}$ terjadi intrusi air laut. Lapisan lempung memiliki nilai resistivitas $2,22-5,35 \Omega \mathrm{m}$. Hal ini didukung oleh penelitian sebelumnya yang dilakukan oleh Purnama dkk [2] yang menunjukkan bahwa pada range resistivitas $3,00-8,30 \Omega \mathrm{m}$ merupakan lapisan lempung [20]. Lapisan lempung pasiran mempunyai rentang nilai resistivitas $4,25-9,88 \Omega \mathrm{m}$. Hal ini didukung hasil penelitian di Desa Kesugihan Kidul oleh Zen [21] yang lokasinya dekat dengan daerah penelitian yang menyatakan bahwa pada range resistivitas 7,50-12,4 $\Omega \mathrm{m}$ merupakan lapisan lempung pasiran [21]. Lapisan pasir lempungan memiliki rentang nilai resistivitas $>7,86 \Omega \mathrm{m}$. Jenis lapisan tersebut didukung oleh hasil penelitian sebelumnya di Desa Gombol Harjo Kecamatan Adipala oleh Rachman [22] yang lokasinya relatif berdekatan dengan daerah penelitian, yang menyatakan bahwa pada range resistivitas $11,43-29,53 \Omega \mathrm{m}$ merupakan lapisan pasir lempungan [22].

Jenis air tanah yang terkandung di dalam lapisan pasir lempungan dan lempung pasiran dengan range resistivitas 4,25 hingga $>7,86 \Omega \mathrm{m}$ merupakan air payau. Air tanah asin dengan range resistivitas $0,20-5,35 \Omega \mathrm{m}$ terkandung pada lapisan lempung dan lapisan pasir yang diduga terintrusi air laut. Klasifikasi jenis air tanah berdasarkan nilai resistivitas, pernah dilakukan Hazreek dkk [23] di area pesisir Malaysia, dimana diperoleh hasil bahwa air asin memiliki range nilai resistivitas $0,1-5 \Omega \mathrm{m}$, sedangkan air payau memiliki range resistivitas $5-15 \Omega \mathrm{m}$. Setelah didapatkan litologi batuan bawah permukaan di setiap lintasan, selanjutnya dilakukan korelasi antar lintasan untuk mengetahui persebaran intrusi air laut yang terjadi. Korelasi antar lintasan dilakukan pada lintasan Wen1, lintasan Wen2, lintasan Wen3, dan lintasan Wen4. Hasil korelasi antar lintasan menggunakan software Voxler 4.0 ditunjukkan pada Gambar 15 dan Gambar 16. 


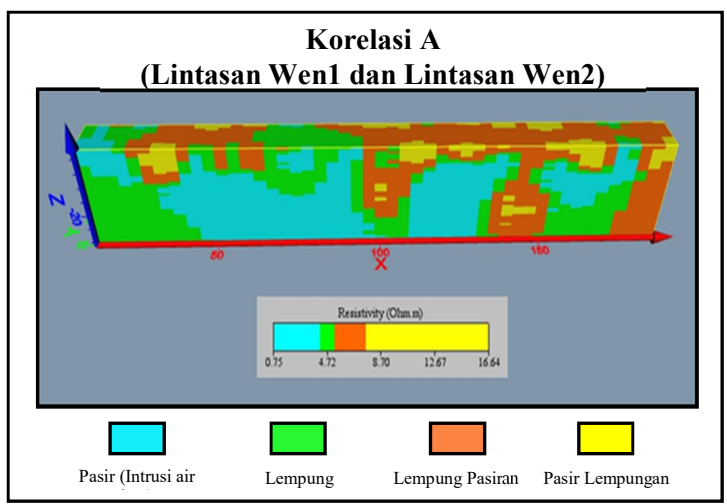

Gambar 15. Korelasi Lintasan Wen1 dan Lintasan Wen2 dalam bentuk penampang resistivitas 3D

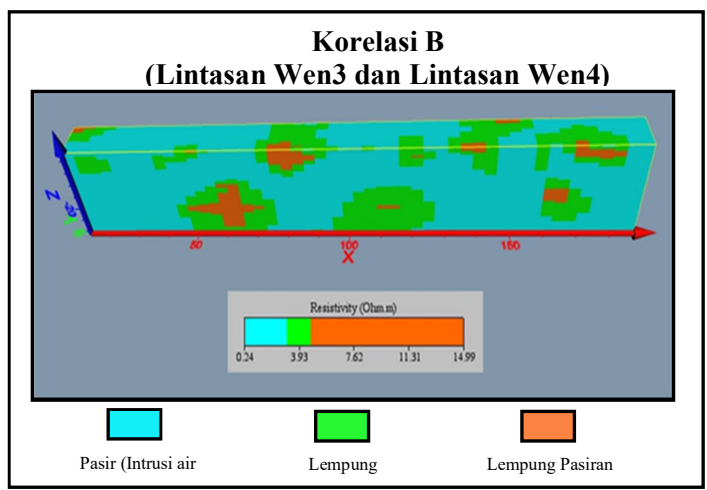

Gambar 16. Korelasi Lintasan Wen3 dan Lintasan Wen4 dalam bentuk penampang resistivitas 3D

Korelasi A antara lintasan Wen1 dan Wen2 mempunyai lokasi yang berbeda dengan korelasi B antara lintasan Wen3 dan Wen4. Korelasi A berada di bagian utara sungai dengan arah bentangan lintasan relatif dari selatan menuju ke utara, adapun korelasi B berada di bagian selatan sungai dengan arah bentangan lintasan relatif dari utara menuju ke selatan. Pada Gambar 15 dan Gambar 16 terdapat tiga sumbu yaitu sumbu X,Y, dan Z. Sumbu X menyatakan panjang lintasan, sumbu $Y$ menyatakan jarak antar lintasan, dan sumbu $\mathrm{Z}$ menyatakan kedalaman yang diperoleh dari penelitian. Hasil korelasi lintasan menunjukkan bahwa semua lintasan telah terintrusi air laut pada kedalaman $\pm 1,25 \mathrm{~m}$ hingga $\pm 28,7 \mathrm{~m}$. Seluruh daerah penelitian telah terintrusi air laut secara merata baik di bagian utara maupun bagian selatan sungai. Intrusi air laut di Desa Ujungmanik diduga berasal dari sungai. Muara sungai yang berjarak \pm 1000 meter dengan laut memungkinkan adanya gerakan air laut mendesak ke arah darat terutama saat terjadi gelombang pasang [2].
Hasil-hasil penelitian ini didukung oleh hasil pengujian konduktivitas terhadap beberapa sampel air tanah. Sampel air tanah diambil pada 15 titik di sekitar daerah penelitian dengan rincian 8 titik berada di bagian utara sungai dan 7 titik berada di bagian selatan sungai. Air tanah yang diambil berasal dari air sumur yang memiliki kedalaman rata-rata $\geq 5$ meter. Sampel air tanah tersebut kemudian diukur nilai konduktivitasnya menggunakan alat EC-meter. Hasil dari pengujian konduktivitas sampel air tanah dapat dilihat pada Tabel 7 dan grafik antara nilai konduktivitas sampel air terhadap jarak yang diukur dari tepi sungai dapat dilihat pada Gambar 17. Selain dibuat grafik, nilai konduktivitas sampel air tanah yang diuji, dipetakan melalui software Surfer 10 sehingga menghasilkan peta kontur konduktivitas air tanah seperti Gambar 18.

Tabel 7. Data pengukuran nilai konduktivitas sampel air tanah

\begin{tabular}{|c|c|c|c|c|c|c|}
\hline \multirow{2}{*}{$\begin{array}{l}\text { Titik } \\
\text { Sampel } \\
\text { Air } \\
\text { Tanah }\end{array}$} & \multirow{2}{*}{ Koordinat } & Uji Kc & nduktiv & $\operatorname{as}(\mu \mathrm{S}$ & \multicolumn{2}{|c|}{$\begin{array}{l}\text { Jarak } \\
\text { dari } \\
\text { Tepi } \\
\text { Sungai } \\
\text { (m) }\end{array}$} \\
\hline & & 1 & 2 & 3 & $\begin{array}{l}\text { Rata- } \\
\text { rata }\end{array}$ & \\
\hline 1 & $\begin{array}{l}7^{\circ} 38^{\prime} 35.06^{\prime \prime L S} \\
108^{\circ} 57^{\prime} 2.62^{\prime \prime B T}\end{array}$ & 1363 & 1360 & 1366 & 1363 & 405 \\
\hline 2 & $\begin{array}{l}7^{\circ} 38^{\prime} 38.94 " \mathrm{LS} \\
108^{\circ} 57^{\prime} 4.56^{\prime \prime} \mathrm{BT}\end{array}$ & 1378 & 1378 & 1378 & 1378 & 300 \\
\hline 3 & $\begin{array}{l}7^{\circ} 38^{\prime} 39.55 \text { "LS } \\
108^{\circ} 57^{\prime} 3.79^{\prime \prime B T}\end{array}$ & 1465 & 1468 & 1461 & 1465 & 280 \\
\hline 4 & $\begin{array}{l}7^{\circ} 38^{\prime} 42.06 " \mathrm{LS} \\
108^{\circ} 57^{\prime} 1.98^{\prime \prime B T}\end{array}$ & 1970 & 1972 & 1977 & 1973 & 190 \\
\hline 5 & $\begin{array}{l}7^{\circ} 38^{\prime} 45.01 \text { "LS } \\
108^{\circ} 57^{\prime} 3.49^{\prime \prime} \mathrm{BT}\end{array}$ & 2317 & 2317 & 2306 & 2313 & 110 \\
\hline 6 & $\begin{array}{l}7^{\circ} 38^{\prime} 45.44 " \mathrm{LS} \\
108^{\circ} 57^{\prime} 1.07 " \mathrm{BT}\end{array}$ & 2510 & 2489 & 2510 & 2503 & 75 \\
\hline 7 & $\begin{array}{l}7^{\circ} 38^{\prime} 46.54^{\prime \prime} \mathrm{LS} \\
108^{\circ} 56^{\prime} 58.19^{\prime \prime} \mathrm{BT}\end{array}$ & 3010 & 3014 & 3012 & 3012 & 30 \\
\hline 8 & $\begin{array}{l}7^{\circ} 38^{\prime} 44.83^{\prime \prime L S} \\
108^{\circ} 56^{\prime} 38.00 " \mathrm{BT}\end{array}$ & 2631 & 2606 & 2606 & 2614 & 50 \\
\hline 9 & $\begin{array}{l}7^{\circ} 38^{\prime} 52.23 \text { "LS } \\
108^{\circ} 57^{\prime} 2.48^{\prime \prime B T}\end{array}$ & 1727 & 1725 & 1702 & 1718 & 75 \\
\hline 10 & $\begin{array}{l}7^{\circ} 38^{\prime} 51.92 " \mathrm{LS} \\
108^{\circ} 57^{\prime} 0.06^{\prime \prime} \mathrm{BT}\end{array}$ & 3534 & 3523 & 3557 & 3538 & 80 \\
\hline 11 & $\begin{array}{l}7^{\circ} 38^{\prime} 50.84 " \mathrm{LS} \\
108^{\circ} 56^{\prime} 54.16^{\prime \prime} \mathrm{BT}\end{array}$ & 4161 & 4144 & 4129 & 4145 & 60 \\
\hline 12 & $\begin{array}{l}7^{\circ} 38^{\prime} 52.38^{\prime \prime L S} \\
108^{\circ} 56^{\prime} 45.88^{\prime \prime} \mathrm{BT}\end{array}$ & 1882 & 1883 & 1881 & 1882 & 125 \\
\hline 13 & $\begin{array}{l}7^{\circ} 38^{\prime} 50.34 \text { "LS } \\
108^{\circ} 56^{\prime} 38.39 " \mathrm{BT}\end{array}$ & 1965 & 1962 & 1962 & 1963 & 80 \\
\hline 14 & $\begin{array}{l}7^{\circ} 38^{\prime} 49.58^{\prime \prime L S} \\
108^{\circ} 56^{\prime} 19.14 " \mathrm{BT}\end{array}$ & 2500 & 2489 & 2493 & 2494 & 95 \\
\hline 15 & $\begin{array}{l}7^{\circ} 38^{\prime} 59.27 " \mathrm{LS} \\
108^{\circ} 56^{\prime} 0.07^{\prime \prime B T}\end{array}$ & 1610 & 1615 & 1614 & 1619 & 430 \\
\hline
\end{tabular}

Berdasarkan data hasil pengukuran konduktivitas air tanah seperti Tabel 7, diketahui bahwa sampel air tanah mempunyai rentang nilai $1.363-4.145 \mu \mathrm{S} / \mathrm{cm}$. Jika nilai 
konduktivitas sampel air tanah yang didapat diklasifikasikan berdasarkan Tabel 2, terdapat dua kelompok air, yaitu kelompok air tawar dengan kisaran nilai $0-1.500 \mu \mathrm{S} / \mathrm{cm}$ dan kelompok air agak payau dengan kisaran nilai $1.500-5.000 \mu \mathrm{S} / \mathrm{cm}$. Nilai konduktivitas sampel air tanah yang didapat tidak sesuai dengan hasil interpretasi resistivitas yang menunjukkan telah terjadi intrusi air laut. Hal ini disebabkan oleh pengambilan sampel air tanah pada saat musim hujan yaitu satu bulan sebelum akuisisi data. Sampel air tanah yang diambil bercampur dengan air hujan sehingga nilai konduktivitas berubah. Menurut informasi dari warga sekitar, pada saat musim kemarau air sumur terasa sangat asin tetapi apabila musim hujan tiba maka air sumur terasa sedikit tawar [5].

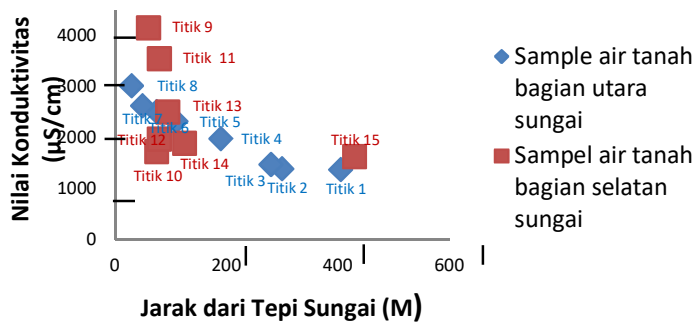

Gambar 17. Grafik perubahan nilai konduktivitas terhadap jarak dari tepi sungai

Gambar 17 menunjukkan perubahan nilai konduktivitas terhadap jarak pengambilan sampel air tanah yang diukur dari tepi sungai. Tren penurunan garis terlihat pada Gambar 17 yang menandakan bahwa terdapat pengaruh jarak dari tepi sungai terhadap nilai konduktivitas sampel air tanah. Semakin jauh jarak dari tepi sungai, semakin kecil pula nilai konduktivitas sampel air tanah [24]. Berdasarkan Gambar 4.13 konduktivitas air tanah pada titik-titik ukur di bagian selatan sungai relatif lebih tinggi daripada di bagian utara sungai. Hal ini menunjukkan bahwa arah aliran air tanah yang terintrusi air laut, sebagian besar ke arah selatan sungai karena topografi bagian selatan sungai relatif lebih rendah dibandingkan bagian utara sungai [25].

\section{KESIMPULAN}

Penelitian pendugaan sebaran intrusi air laut melalui sungai di Desa Ujungmanik Kecamatan Kawunganten Kabupaten Cilacap menggunakan metode resistivitas dengan konfigurasi Wenner telah dilakukan. Hasil-hasil penelitian menunjukkan batuan penyusun bawah permukaan terdiri atas empat lapisan batuan penyusun bawah permukaan yaitu pasir, lempung, lempung pasiran, dan pasir lempungan. Lapisan pasir yang diinterpretasi terintrusi air laut memiliki rentang nilai resistivitas $0,20-2,79 \Omega \mathrm{m}$. Lapisan lempung memiliki rentang nilai resistivitas $2,22-5,35$ $\Omega \mathrm{m}$. Lapisan lempung pasiran memiliki rentang nilai resistivitas $4,25-9,88 \Omega \mathrm{m}$. Lapisan pasir lempungan memiliki rentang nilai resistivitas $>$ $7,86 \Omega \mathrm{m}$.

Setelah penampang 2D litologi batuan bawah permukaan diperoleh, kemudian dilakukan korelasi antar lintasan untuk mengetahui seberapa jauh intrusi air laut yang terjadi. Hasil korelasi antar lintasan menunjukkan bahwa semua lintasan telah terintrusi air laut pada kedalaman $\pm 1,25 \mathrm{~m}$ hingga $\pm 28,7 \mathrm{~m}$. Daerah penelitian telah terintrusi oleh air laut secara merata. Hasil uji konduktivitas terhadap 15 sampel air tanah yang diambil dari sumur-sumur warga di daerah penelitian menunjukkan bahwa sampel air tanah tersebut dikategorikan ke dalam air tawar dan air agak payau. Hasil tersebut belum menunjukkan terjadi intrusi air laut, karena pengambilan air tanah dilakukan ketika musim hujan. Namun indikasi intrusi air laut cukup kuat

\section{UCAPAN TERIMA KASIH}

Penulis menyampaikan penghargaan yang besar kepada Kepala dan PLP Laboratorium Elektronika, Instrumentasi, dan Geofisika, Fakultas Matematika dan Ilmu Pengetahuan Alam, UNSOED atas peralatan Resistivitymeter dan seluruh instrumen pendukungnya yang disediakan. Terimakasih juga disampaikan kepada tim akuisisi data di lapangan yang telah bersusah payah membantu penulis melakukan akuisisi data resistivitas di Desa Ujungmanik, Kecamatan Kawunganten, Kabupaten Cilacap.

\section{DAFTAR PUSTAKA}

[1] S. Purnama, M. A. Marfai, Saline, "Water Intrusion Toward Groundwater: Issues and Its Control", Journal of Natural Resources and Development 2 (2012) 25-32.

[2] S. Purnama, A. Cahyadi, E. Febriata, N. Khakhim, H. Prihatno, "Identifikasi Airtanah Asin Berdasarkan Pendugaan 
Geolistrik di Pesisir Kota Cilacap Jawa Tengah, Geomedia 11(2) (2013) 183-190.

[3] S. K. Goyal, "Vulnerability and Sustainability of Groundwater Resource in India", Cloud Publications International Journal of Advanced Earth Science and Engineering 2 (1) (2013) 69-74.

[4] T. K. Sidhy, Bencana Kekeringan di Cilacap Meluas, Cilacap: ANTARA (2018).

[5] Karno, Wawancara tentang Kondisi Sumur Warga. Desa Ujungmanik, Kecamatan Kawunganten, Kabupaten Cilacap, 2019.

[6] W. Sumartono, Y. Arman, Y. S. Putra, "Identifikasi Sebaran Bijih Besi di Kabupaten Bengkayang Menggunakan Metode Geolistrik Resistivitas", Prisma Fisika 1 (1) (2013) 14-21.

[7] N. Muna, "Penentuan Zona Intrusi Air Laut Daerah Pantai Selatan Banyuwangi dengan Metode Geolistrik Tahanan Jenis (Studi Kasus Desa Sumbersari Kecamatan Purwoharjo Kabupaten Banyuwangi)", Skripsi, Universitas Islam Negeri Maulana Malik Ibrahim, Malang, 2017.

[8] E. Yuliana, F. X. Tryono, E. Minarto, "Aplikasi Metode Geolistrik Tahanan Jenis untuk Identifikasi Zona Bidang Gelincir Tanah Longsor Studi Kasus Desa Nglajo Kec. Cepu Kab. Blora", Sains dan Seni ITS 6 (2) (2017) B37-B42.

[9] W. Telford, L. Geldart, R. Sheriff, Applied Geophysics Second Edition, Cambridge University, New York, 1990.

[10] M. H Loke, R. D. Barker, Rapid LeastSquares Inversion of Apparent Resistivity Pseudosection by A Quasi-Newton Method, Geophysical Prospecting Press. Inc. , Orlando-Florida, 1996

[11] M.Saila, Muhajjir, Azmeri, "Pengaruh Intrusi Air Laut Terhadap Akuifer Pantai pada Kawasan Wisata Pantai Iboih Sabang”, Konferensi Nasional Teknik Sipil 7 24-26 Oktober 2013, Universitas Sebelas Maret, Surakarta, 2013, hal. 137-143.

[12] P. M.Barlow, Ground Water in Freshwater-Saltwater Environments of the Atlantic Coast. USGS, 2003.
[13] N. N.Pujianiki, N. N. Simpen, "Apilkasi Geolistrik pada Pemetaan Daerah Intrusi Air Laut di Pantai Candidasa", Media Komunikasi Teknik Sipil 24(1) (2018) 2934.

[14] J. Westra, J. Wals, "Overexploitation of coastal aquifers". Cases in Bioplanet Earth (2015) 7-12.

[15] R. S. Waspodo, S. Kusumarini, V. A. Dewi, 'Prediksi Intrusi Air Laut Berdasarkan Nilai Daya Hantar Listrik dan Total Dissolved Solid di Kabupaten Tangerang', Teknik Pertanian Lampung 8 (4) (2019 243-250.

[16] T. Edwin, R. A. Regia, F. Dibba, "Indikasi Intrusi Air Laut dari Konduktivitas Air Tanah Dangkal di Kecamatan Padang Utara", Seminar Nasional Sains dan Teknologi Lingkungan II 19 Oktober 2016, 2016, 152-156.

[17] T. O. Simandjuntak, Surono, Peta Geologi Lembar Pangandaran, Jawa. Pangandaran. 1992.

[18] E. A. Idogbe, A. L. Ahmed, K. M Lawal, B. M. Ahmed, M. M. Isah, "2D Electrical Resistivity Imaging of Mine Workings at Odogbo, North Cerntral Nigeria', FUDMA Journal of Science 3(3) (2019).

[19] H. M. Loke,. Res2dinv Rapid 2D Resistivity \& IP Inversion, for Windows $X P /$ Vista, Goetoma Software, Malaysia, 2009.

[20] S. Purnama, E. Febriarta, A. Cahyadi, N. Khakhim, L. Ismangil, H.Prihatno, "Analisis Karakteristik Akuifer Berdasarkan Pendugaan Geolistrik di Pesisir Kabupaten Cilacap Jawa Tengah", Jurnal Geografi 11 (22) (2013 155-156.

[21] M. T. Zen, Investigasi Batuan Penyangga DAS Serayu Desa Kesugihan Kidul Kecamatan Kesugihan Kabupaten Cilacap Berdasarkan Survei Geolistrik Resistivitas, Skripsi, Universitas Jenderal Soedirman, Purwokerto, 2007.

[22] A. RachmanPendugaan Intrusi Air Asin di Desa Gombol Harjo Kecamatan Adipala Kabupaten Cilacap Menggunakan Metode Geolistrik Resistivitas Konfigurasi Schlumberger, Skripsi. Universitas Jenderal Soedirman, Purwokerto, 2007. 
[23] Z. A. Hazreek, M. M. Hashim, A. M. Asmawisham, Z. M. Hafiz, Y. M.Fairus, K. A. Fahmy, "Seawater Intrusion Mapping Using Electrical Resistivity Imaging (ERI) at Malaysian Coastal Area", International Journal of Civil Engineering and Technology 9(9) (2018 1185-1193.
[24] D. Darmanto, A. Cahyadi, "Kajian Intrusi Air Laut Melalui Sungai di Pesisir Kabupaten Demak Jawa Tengah", Majalah Geografi Indonesia 27(1) (2013) 1-10.

[25] Sehah, W. T. Cahyanto, Pengujian Daya Hantar Listrik Air Tanah di Sekitar Tempat Pembuangan Akhir Gunung Tugel Kabupaten Banyumas Menggunakan Prinsip Jembatan Wheatstone, Molekul 4(1) (2009 39-47. 